\title{
含アルミナベルモライトの水熱生成におよぼす パイロフィライトの影響
}

\author{
久保和彦*・箕浦立八* ・高橋輝**。田村英雄 $* * *$

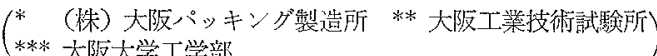

\section{Influence of Pyrophyllite to Affects on Hydro-thermal Synthesis of Al-Containning Tobermorite}

By

Kazuhiko KUBO*, Tatsuya MINOURA*, Akira TAKAHASHI** and Hideo TAMURA***

$$
\left(\begin{array}{rl}
* & \text { Osaka packing manufact. Co., Ltd. Gifu } \\
* * & \text { Government Industrial Research Institute, Osaka } \\
* * * * & \text { Department of Chemical Technology, Faculty of Engineering, } \\
& \text { Osaka University, Osaka }
\end{array}\right)
$$

Hydro-thermal synthesis on the aluminium ion containing tobermorite was studied using pyrophyllite as a source of $\mathrm{Al}_{2} \mathrm{O}_{3}$. Reactivity of pyrophyllite in the system $\mathrm{CaO}-\mathrm{Al}_{2} \mathrm{O}_{3}-$ $\mathrm{SiO}_{2}-\mathrm{H}_{2} \mathrm{O}$ and the influence of $\mathrm{Al}_{2} \mathrm{O}_{3}$ on the crystal structure of the product were investigated through the preparation of hydrous calcium silicate crystals containing various amount of $\mathrm{Al}_{2} \mathrm{O}_{3}$. In general, pyrophyllite had been considered stable chemically, but it was proved that pyrophyllite had a special reactivity in the hyhdro-thermal treatments, that is, according to our results, more than $54 \%$ of $\mathrm{Al}_{2} \mathrm{O}_{3}$ in pyrophyllite was participated in the reaction for $8 \mathrm{hrs}$ treatment and more than $63 \%$ of $\mathrm{Al}_{2} \mathrm{O}_{3}$ was similarly for 24 hrs treatment at $175^{\circ} \mathrm{C}$.

Tobermorite contained $\mathrm{Al}_{2} \mathrm{O}_{3}$ higher than $3 \%$ shown the structural disorder, and the lattice constant of tobermorite crystals which were prepared by the experiment, was changed by addition of pyrophyllite up to $7 \%$, as $\mathrm{Al}_{2} \mathrm{O}_{3}$ for the system $\mathrm{CaO}-\mathrm{Al}_{2} \mathrm{O}_{3}-\mathrm{SiO}_{2}-\mathrm{H}_{2} \mathrm{O}$.

Consequently, Al-containing tobermorite is distinguished from Al-free tobermorite by the X-ray diffraction analysis, D.T.A. and the electron diffraction patterns. These without Al-containing tobermorite and hydrogarnet were produced by addition of pyrophyllite more than $7 \sim 9 \%$ as $\mathrm{Al}_{2} \mathrm{O}_{3}$.

[Received May 21, 1970]

\begin{abstract}
1. 緒事
$\mathrm{CaO}-\mathrm{SiO}_{2}-\mathrm{H}_{2} \mathrm{O}$ 系トぶルモライト $\left(\mathrm{Ca}_{5} \mathrm{Si}_{6} \mathrm{O}_{17} \cdot 5 \mathrm{H}_{2} \mathrm{O}\right)$ の合成に抒いて，アルミナの存在が石灰と珪酸の反底に 関与し，その結晶化促進に効果のあることは，すでに酦

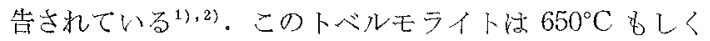
注それ以上の高温に耐える断熱材（保温材）として優れ た特性をもつもので，徒来から蒸気配管や炉壁の断熱用 しして使用されているが, 最近では建築分野でも注目さ れてきた。
\end{abstract}

このようにトベルモライト基性よする製品の用途

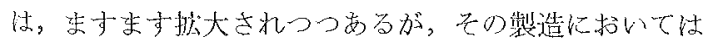
加忹下での水熱逃理を必要とするため，これを合理化す るための研究が多くなされている。そこで前記のアルミ ナの作用孛有效に利用するため，工業的なアルミナ源と して比較的安価に入手できるパイロフィライトを使用寸 ることが考えられる.しかし，パイロフィライトのこの
系に招ける反応性と生成物に与える影譭についての報告 壮少なく, わず加に近藤, 大沢ら ${ }^{3)}$ と真木, 小泉, 久保 ら²) 報告があるにすぎない。

$\mathrm{CaO}-\mathrm{SiO}_{2}-\mathrm{H}_{2} \mathrm{O}$ 系に関古研究は 1800 年代加方主 としてセメント化学分野に执いてなれて祘り，J.N.

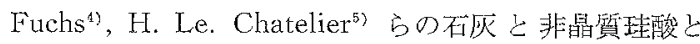
の反底に上る凝結力に関する報告，E。. J.Ordis， E.H. Kanter $ら^{6)}$ の石灰と非鼠質珪酸の反忘による生成物に

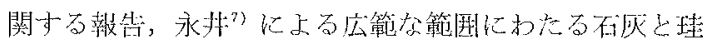

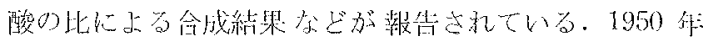
以後に沶えと I. Heller, H.F.W. Taylor $5^{8)}$ にり 系統的な研究がなされ，また多くの研究者によ石研究綜 果が報告され，学問的にも大きく飛躍寸るところとな り, Taylor $^{9}$ はこれら多くの研究結果を集約した。この 閒，特にアメリカに扔いては工業的利用分野として断熱 材関係の多くの特許が確立されてきた。 
一方, $\mathrm{CaO}-\mathrm{Al}_{2} \mathrm{O}_{3}-\mathrm{SiO}_{2}-\mathrm{H}_{2} \mathrm{O}$ 系の研究については G.L. Kalousek ${ }^{13,10)}$ がこの系の反応ではトベルモライ ト中の $\mathrm{Si}^{4+}$ の一部が $\mathrm{Al}^{3+}$ と置狙され含アルミナト心゙ リモライト（Al-Containing tobermorite）を生成する こと老報告し，また S. Diamond, J.L. White ら トベルモライト結晶の $\mathrm{Si}^{4+}$ と $\mathrm{Al}^{3++}$ が置換した場合, X線回折で (002) の面間隔が増大してシフトすること や，D.T.A. で発熱ピークが高温測に移動することのほ か， $\mathrm{Al} / \mathrm{Si}$ の原子比が 15\% まで置換可能であること， 蛍光 X 線分析で $\mathrm{Al}^{3+}$ が 4 配位と尔ることを D.M. Roy ${ }^{12)}$ はアルミナを加えることにより，ドベルモライト の結晶化が促進するとともに相の熱安定が上昇すること を報告している。

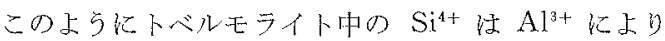
犆換されることがよく知られるに至ったが，従来一般に 反応性注覀いとされていたパイロフィライトが工業的に 安㜀比入手し得るところから，これの反度性を知り工業 的生産に店用できれ列コス卜低減に役立つこと，さらに は適正使用量を知ることなどを目的として本研究を行小 ったものである。

すなわ化学分析によるアルミナの反忘量, X線回折 による生成物の同定と結晶度，さらに将 $\mathrm{A}$ 置換による 影響, 示差熱分析に上る熱的性質, 電子顕微鏡による結 晶形態, 電子線回析によるアルミナの反応が結晶構造に およぼ寸影響などについて，それぞれ検討を行なった。

\section{2. 害験}

\section{1 使用原料之調合比}

使用原料恃特級試薬炭酸カルシウムを $1050^{\circ} \mathrm{C}$ で 5 時 間焼成して得た生石灰 $(\mathrm{CaO} 98.2 \%)$ と, 試薬用石英 $\left(\mathrm{SiO}_{2} 97.12 \%, \mathrm{Al}_{2} \mathrm{O}_{3}\right.$ 1.64\%, Ig loss 0.09\%), アルミ ナ源としてパイロフィライト(工業用クレー, $\mathrm{SiO}_{2} 73.02$ $\%, \mathrm{Al}_{2} \mathrm{O}_{3} 21.2 \%$, Ig loss 4.14\%) 拈上び比較笑験用と して無アルミナトベルモライトの合成に純石英（ブラジ 儿産水晶微粉末 $\mathrm{SiO}_{2}$ 99.999\%) 孛使用した。

な扔石英，パイロフィライトはいずれも 325 メッシュ 全道に微粉砕されたものを使用した。

これらの各原料をトベルモライト $\left(\mathrm{Ca}_{5} \mathrm{Si}_{6} \mathrm{O}_{17} \cdot 5 \mathrm{H}_{2} \mathrm{O}\right)$ の $\mathrm{CaO} / \mathrm{SiO}_{2}$ のモル比に従って配合しアルルトナは $0 \%$

Table 1. Compositions of starting material.

\begin{tabular}{|c|c|c|c|c|c|}
\hline \multirow[b]{2}{*}{ No. } & \multicolumn{3}{|c|}{ Composition (weight $\%$ ) } & \multirow{2}{*}{$\begin{array}{l}\text { molar ratio } \\
\mathrm{CaO} / \mathrm{SiO}_{2}\end{array}$} & \multirow{2}{*}{$\begin{array}{l}\text { contents } \\
\mathrm{Al}_{2} \mathrm{O}_{3}(\%)\end{array}$} \\
\hline & $\widetilde{\text { Lime }}$ & Quartz & $\mathrm{Clay}^{* 5}$ & & \\
\hline $\mathrm{A}-0$ & 44.1 & 55.9 & & 0.83 & 0 \\
\hline$A-1$ & 43.4 & 56.6 & & 0.83 & 1 \\
\hline$A-3$ & 42.3 & 47.2 & 10.5 & 0.83 & 3 \\
\hline$A-5$ & 41.2 & 38.2 & 20.6 & 0.83 & 5 \\
\hline A -7 & 40.1 & 29.1 & 30.8 & 0.83 & 7 \\
\hline A-9 & 39.0 & 20.0 & 40.9 & 0.83 & 9 \\
\hline $\mathrm{A}-14$ & 36.5 & & 63.5 & 0.83 & 14 \\
\hline
\end{tabular}

*6 Pyrophyllite
加ら $14 \%$ まで含むように添加した。配合比中の珄酸量 はパイロフィライト中の $\mathrm{SiO}_{2}$ 量も加算した。

この配合比定 表-1 に示す。

\section{2 試料の調製}

表-1 に決められた各配合比により，各原料の全量が $10 \mathrm{~g}$ となるよらに精秤し, 使用水量は酸化カルシウムの 消和と原料の分散混合が十分に行なわれるに必要な流動 性を付与するために，水対固体分の比を 4 対 1 (重量比) とした、試料の調製は $60^{\circ} \mathrm{C}$ の蒸溜水中でまず酸化カル シウムを消和したのち，他の原料学加えて十分擋拌混合 した. 次いで，このスラリーを容器ごと（ステンレス 製）にオートクレーブ中に入れ，飽和蒸気压下 $8.2 \mathrm{~kg} /$ $\mathrm{cm}^{2}(\mathrm{G}) 175^{\circ} \mathrm{C}$ で 8 時間抒よび 24 時間, で抒の扝の水 熱反応させ，これを $105^{\circ} \mathrm{C}$ で 20 㭙間乾燥した。試料法

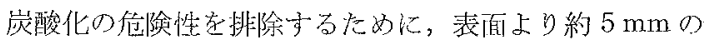
厚さの部分を除いたものを各実験に供した。

な㧍, 水熱処理後の試料と比較検討のために, X線湴 析実驗では原料混合物をも試料とした。

\section{3. 実験 結 果}

\section{$3.1 \mathrm{X}$ 線回折}

X線回折装置にはフィリップス社製 PW 1050 を使用 L, $\mathrm{Cu} \mathrm{K}_{\alpha}, \mathrm{Ni}$ フィルター, $40 \mathrm{kV}, 20 \mathrm{~mA}$, 受光スリ ット $0.2 \mathrm{~mm}$, スケールファクター 8 , 恃定数 4 , 走查速 度は $2 \theta 1 \% \mathrm{~min}$, および精密測定には $0.25^{\circ} \mathrm{min}$ で行な った。

\section{1 .1 パイロフィライトの反応性亡生成結晶}

図-1,2 亿示寸上らに原料混合物と水熱反忘後の 各試 料を比較すると，原料混合物で高い回折強度を示してい るパイロフィライトの回折線も，水熱反応後で注大きく 減少，あるい恃消滅していることがあきらかである。

すなわち，石灰とクレ一のみを配合した原料混合物の 試料 (A-14) によるパイロフィライトの回折強度 (002) を 100 として，これ対する各試料の回折強度比を検討 してみると，図-2 のように，原料混合物の回折强度に 対して，水熱処理した試料で性大きてその強度が低下し ている、これはとりもな捛さず，パイロフィライトの大 半が反応したことを示すものであってこの結果恃後記 の化学分析による結果と不溶残のX線回折による結果を あわせて検討するこにより。よりあきらかとなったもの である。

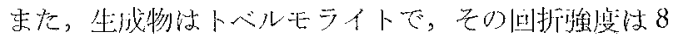

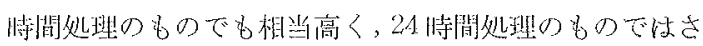
さらに高い回折强度を示した。

区応系 $\left(\mathrm{CaO}-\mathrm{Al}_{2} \mathrm{O}_{3}-\mathrm{SiO}_{2}-\mathrm{H}_{2} \mathrm{O}\right)$ に括汀るアルミナの 作用をトベルモライトの $(002)$ 回折強度でみると， 8 時 間処理の場合，その添加量が $3 \%$ の -3 で最も高く, 以下 $\mathrm{A}-5>\mathrm{A}-1>\mathrm{A}-7$ の順に。2 24 時間処理で注同じく 
$\mathrm{A}-3$ が最高の回折强度となり，以下 $\mathrm{A}-1>\mathrm{A}-5>\mathrm{A}-7$ の順となった。京た 8 時間処理で注 $9 \% ， 24$ 洔閒処理で は7\% 以上のアルミナ添加量となると八イドロガーネッ 卜の生成がみられ，トベルモライトの回折強度は相刘的 儿低下寸る低向を示した。

これらの結果は図-1 と図-3により示されるトベルも ライトの回折強度からあきらかである。

またトベルモライトの (222) 回折強度注 8 時間処理の 場合，アルミナ添加量の増加が 7\%までは，その回折強 度流くなり，9\% 以上になると低下し始める。これに 対し 24 時間処理の場合，アルミナ添加量が $3 \%$ を越光 ると低下し始め，9\% 以上となってむほとんど変化しな い.

以上のようにトベルモライトの (222) も (002) の回折 強度変化とほぼ同樣な傾向を示すが，いずれも 8 時間处

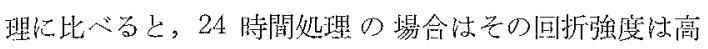

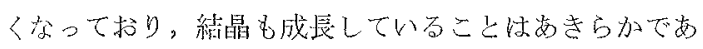
万.
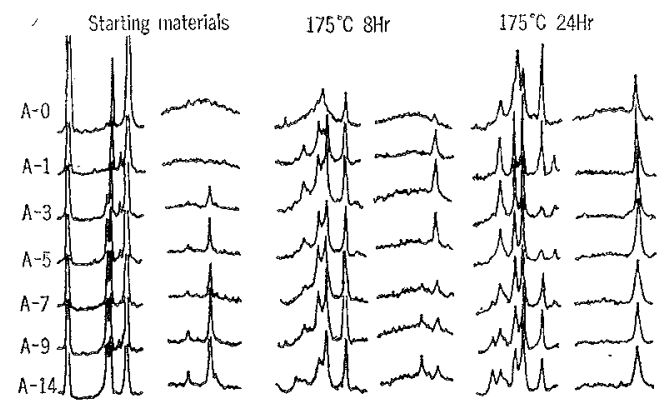

$3 5 \longdiv { 3 0 } 2 5 1 5 \longdiv { 1 0 6 }$

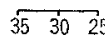

$(2 \theta)$

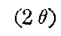

Fig. 1. X-ray diffraction patterns for the mixture of starting materials and product of hydrothermal reactions.

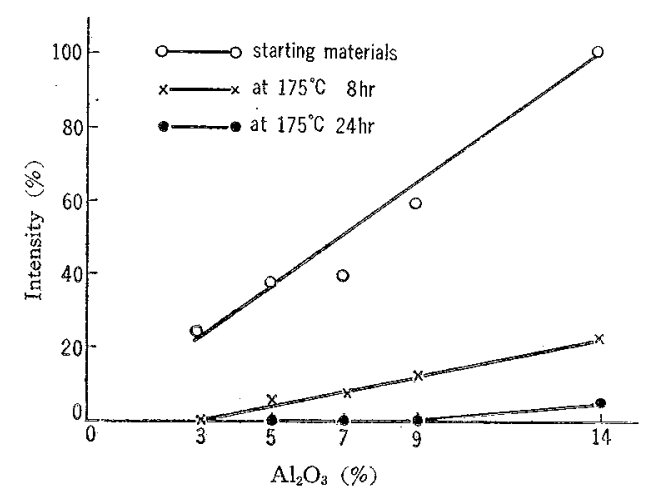

Fig. 2. Intensities of X-ray diffraction patterns for the pyrophyllite (002).

注 図一 2 と図一 3 の回折強度恃, そ机ぞれの最高強度（回折 ピークの高さ）を100とし，卆れに対する比亱で示したもので める。

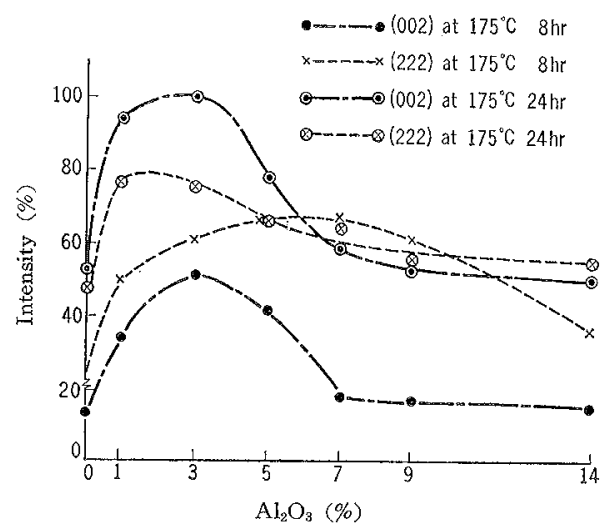

Fig. 3. Intensities of $\mathrm{X}$-ray diffraction patterns for the tobermorite.

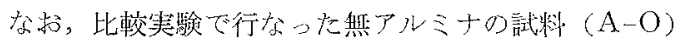
では 8 時間の水熱处理で C-S-H(I), 24 侍閒の处理で驻 トベルモライトとごく少轱のゾノトライトを生成してい た。

\section{1 .2 アルミニウム犆換による影響}

アルミニウム置撸による影響はトベルモテイトの (002)面と(400)面の回折汇現われている。トベルモライ トの結晶構造については H.D. Megaw, C.H. Kelsey ${ }^{13}$ らによって $a=11.3 \AA, b=7.33 \AA, c=22.6 \AA$ であるこ とが報告されているが，われわれの実験では $(002)$ 面の

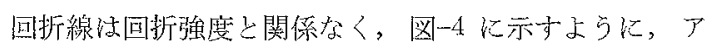
ルミナ添加量の増加とともに $d$ 值が $11.26 \AA$ 付近汃ら $11.6 \AA$ 付近までほぼ直線的に増加し，7\% 以上の添加 ではほとんど平衡状態となった。 また (400) 面の回折線 証逆に $d$ 值が $2.83 \AA$ 付近から $2.80 \AA$ 付近まで, こ れもほ声線的に滅少した。これらの結果からトベルモ ライト結晶の格子定数 $c_{0}$ と $a_{0}$ はアルミナを添加する ことによって增減することは山きらかである。

すなわち，無アルミナトベルモライトの $c_{0} \doteqdot 22.6 \AA$, $a_{0} \doteqdot 11.32 \AA$ から含アルミナトベルモライトでは $c_{0} \doteqdot$ $23.2 \AA, a_{0} \doteqdot 11.22 \AA$ となることである。

このように格子定数が変化することは, 粘上鉱物のよ らに $A 1^{3+}$ イオンの置換によって $a$ 朝江減少し, $c$ 軸驻

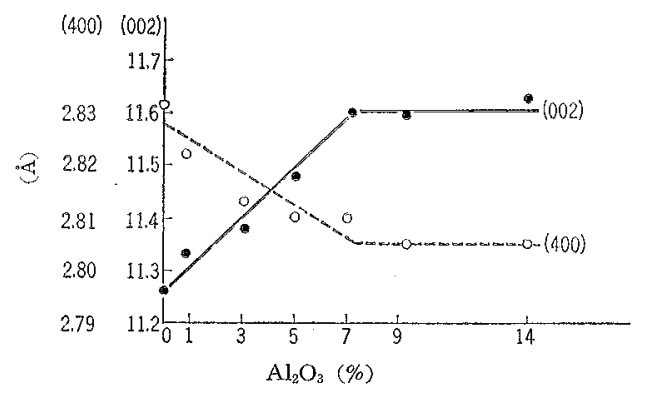

Fig. 4. Relation between spacings and contents of $\mathrm{Al}_{2} \mathrm{O}_{\hat{3}}$ 。 


\section{Yogyo-Kyokai-Shi 79 [2] 1971}

増大することがらして $\mathrm{Si}^{4+}$ イオンと $\mathrm{Al}^{3++}$ イオンの置 换することによりトベルモライトの結晶構造に焔在生 じていることはあきらかであるまた，アルミナ添㞦量 が 7\% 以上になると $d$ 值の変動が平衡状態になるのは, アルミニウム置換の限界がこの付近にあり，それ以上ア ルミナが存在するときは, 別の結晶（ハイドロガーネッ

ト）を生成してくるためでめららと考えられる.

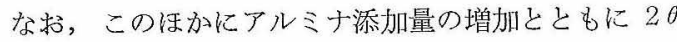
$\doteqdot 32.8 \AA, d \doteqdot 2.72 \AA$ 付近に回折線が現われこれもケ ルミナの作用と考えられた (図-1 参照).

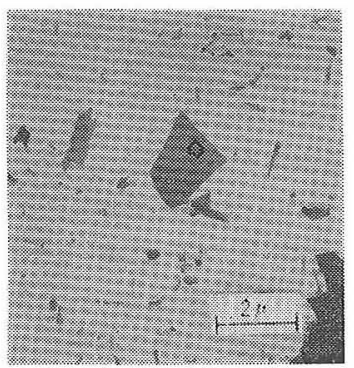

A-0

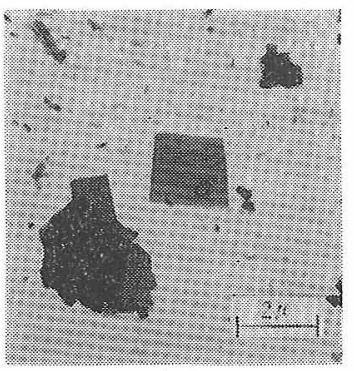

A-3

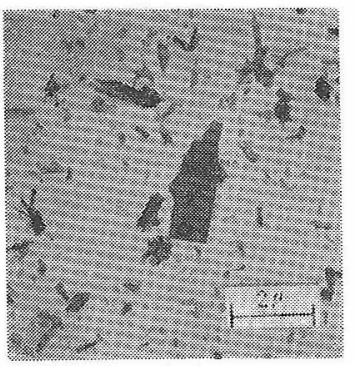

A-7

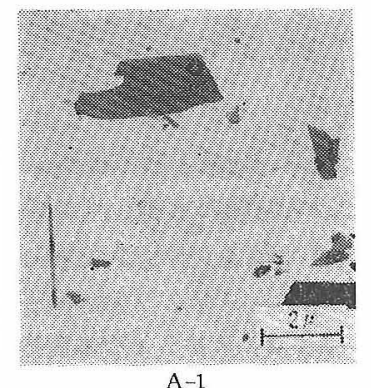

A-1
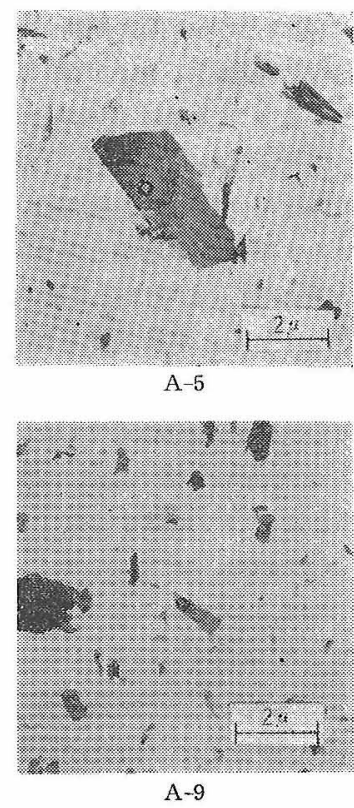

A -9

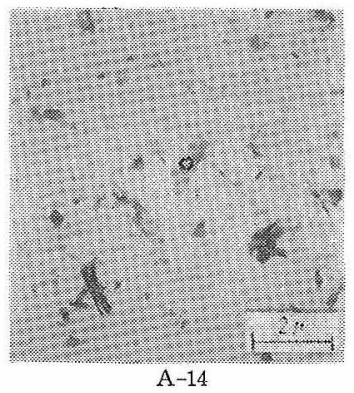

Fig. 5. Electron photomicrograph for the tobermorite at $175^{\circ} \mathrm{C} 24 \mathrm{hr}$.
3.2 電子顕微鏡写真 と制限視野電子線回折図による 観察

生成結晶の形態観察と結晶度の検討，電子線回折では 生成結晶の構造的検討とアルミナの作用等について検討 したもので, 使用機器は日本電子 (株) JEM-5 を使用し た・試料は試験管中でアルコールを加え,超音波分散させ た㲘濁液をカーボン膜上にピペットで滴下し調製した。

観察結果では 8 時閒, 24 時間処理の各試料ともにトべ ルモライトの板状結晶を主体とした。アルミナ添加量が $9 \%$ 以上では㤆上の微小結晶が比較的に多く，1\%以下 では纎維状をるいは針状の結晶が少量混在することを確 認した.これらの結果のらち24 時間処理の試料の電子 顕微鏡写真を図 -5 に示す.

また，この試料を制限視野で電子線回折した結果では $3 \%$ 以上のアルミナを添加すると，k=odd レイヤーで $a^{*}$ 軸に平行な特徴岁るストリークを示し，トベルモラ イトの回折と含アルミナ・トベルモライトの国折はあき ら汃に相違すること妾確認した。これらのらちから A-1 の試料とA-5の証料を選び，その電子線回折図を図-6 に示す。なお図 -5 の○印は電子線回折部位を示し，電 子線回折による念アルミナ・・トベルモライトと無アルミ

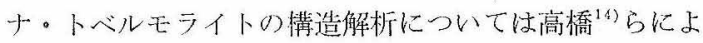
り啹告されている。

\section{3 示差熱分析}

使用した機器は島津製作所 OT-1 A 型示差熱分析装 置であり，測定条件は感度 $X$ 軸 $16 \mathrm{mV}, Y$ 軸 $\pm 100 \mu \mathrm{V}$, 加熱速度は $5^{\circ} \mathrm{C} / \mathrm{min}$, 標準試料は $\alpha$ アルミナ粉末， ホ

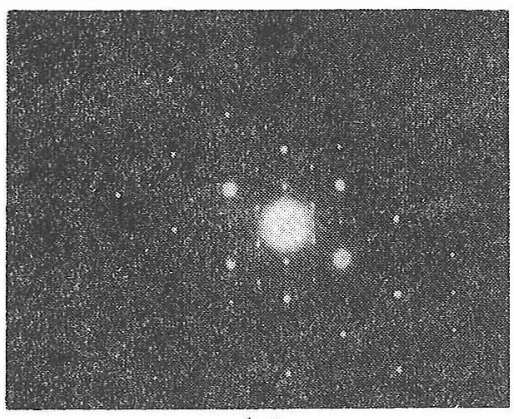

A-1

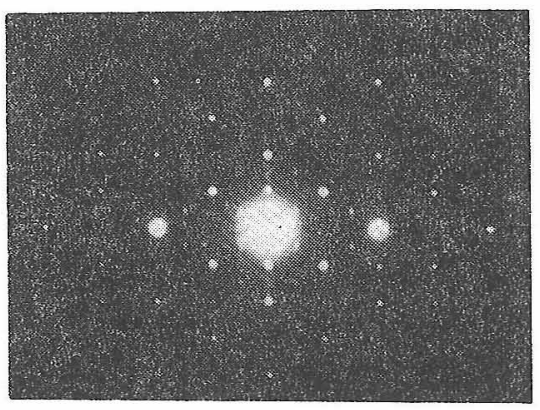

A-5

Fig. 6. Electron diffraction diagram for the tobermorite 


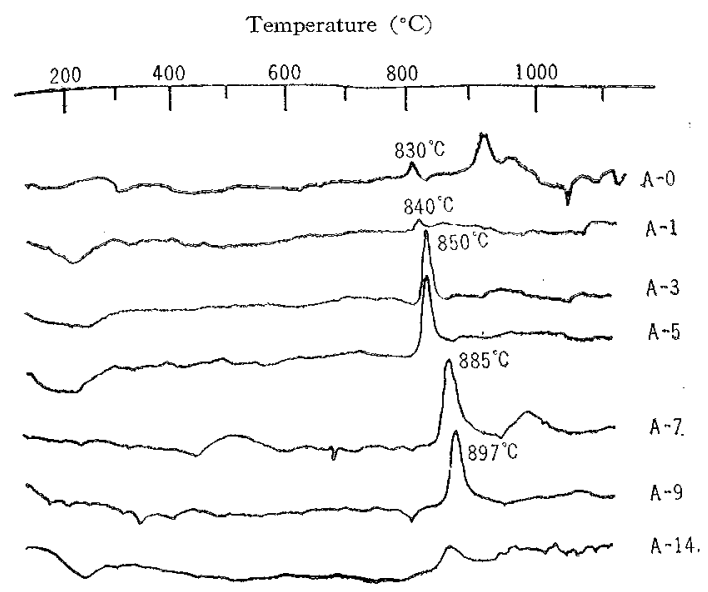

Fig. 7. DTA results on products prepared at $175^{\circ} \mathrm{C}$ for $24 \mathrm{hr}$ of autoclaving.

一ルダーは白金製とし，24 時間処理したものの結果定 図 7 に示子.

この絬果，アルミナ添加量の増加とともに発熱ピーク 注高温側入移動し, アルミナ添加量功 3〜 $5 \%$ では $850^{\circ} \mathrm{C}$ 付近, $7 \%$ 以上で法 $885^{\circ} \mathrm{C}$ から $895^{\circ} \mathrm{C}$ 程度の範囲とな り，G.L. Kalousek ${ }^{1)}$ の報告とほぼ闰様の結果となっ to.

これらの結果汃ら，アルミナ添加量が 196以ではト ベルモライト，3〜5\% では含アルミナ。トベルモライ ト，7\% 以上で结含アルミ十・トベルモライトとハイド 口ガーネットが其存しているよらに考えられた。

\section{4 化学分新}

JIS-R 5202 によりアルミナの反応量を測定した結果, 表一2 に示すよらにアルミナ添加量の増加とともに反応 したアルミナの量は増加したが, 反志率としては逆に低 下した. すな子ち 8 時間，24 時間水熱処理したいずれ の試粼も反応したアルミナの量は A-14の試料が最も多 いが反応率としては、この A-14が最小となった。しか しパイロフィライト中のアルミナ反応率は 8 時䦔の処理 で $54 \%$ 以上，24街閒処理で侍 $63 \%$ 以上が反応寸るこ と学確認した。

Table 2. Chemical analysis for the $\mathrm{Al}_{2} \mathrm{O}_{3}$ reactions

\begin{tabular}{ccccc}
\hline $\begin{array}{c}\text { addition of } \\
\mathrm{Al}_{2} \mathrm{O}_{3}(\%)\end{array}$ & $\begin{array}{c}\text { chemical } \\
\text { analysis }\end{array}$ & $\begin{array}{c}175^{\circ} \mathrm{C}, 8 \mathrm{hr} \\
\text { rate of } \\
\text { reaction }(\%)\end{array}$ & $\begin{array}{c}175^{\circ} \mathrm{C}, 24 \mathrm{hr} \\
\begin{array}{c}\text { chemical } \\
\text { analysis }\end{array}\end{array}$ & $\begin{array}{c}\text { rate of } \\
\text { reaction (\%) }\end{array}$ \\
\cline { 1 - 4 } 3 & 2.49 & 83.0 & 2.80 & 93.3 \\
5 & 3.61 & 72.2 & 4.35 & 87.0 \\
7 & 4.31 & 63.1 & 5.62 & 80.2 \\
9 & 5.01 & 55.6 & 6.96 & 77.3 \\
14 & 7.63 & 54.5 & 8.89 & 63.5 \\
\hline
\end{tabular}

\section{5 不溶残分の X 線回折}

JIS-R 5202 に従って試料を処理し，不溶残分它濾別 水洗した後乾燥しこれを試料としてX線回折により末 反応物の同定とパイロフィライトの反応性を検討した。
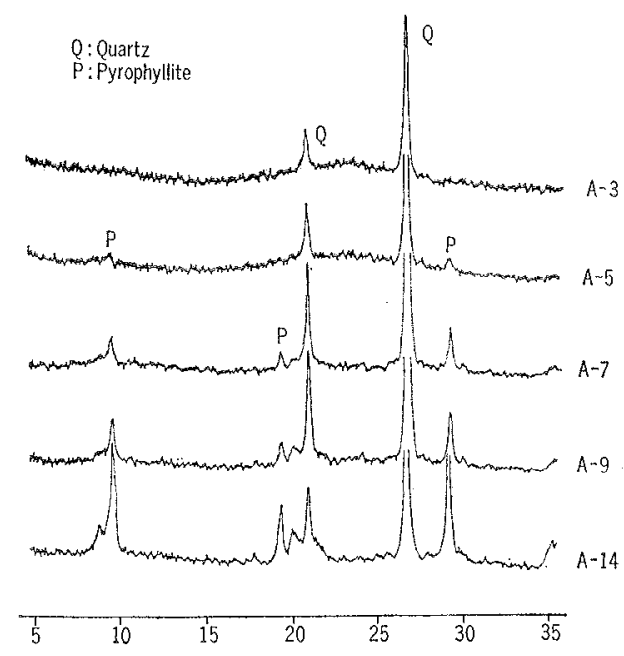

Fig. 8. X-ray diffraction patterns for the insoluble residue. at $175^{\circ} \mathrm{C} 8 \mathrm{hr}$.
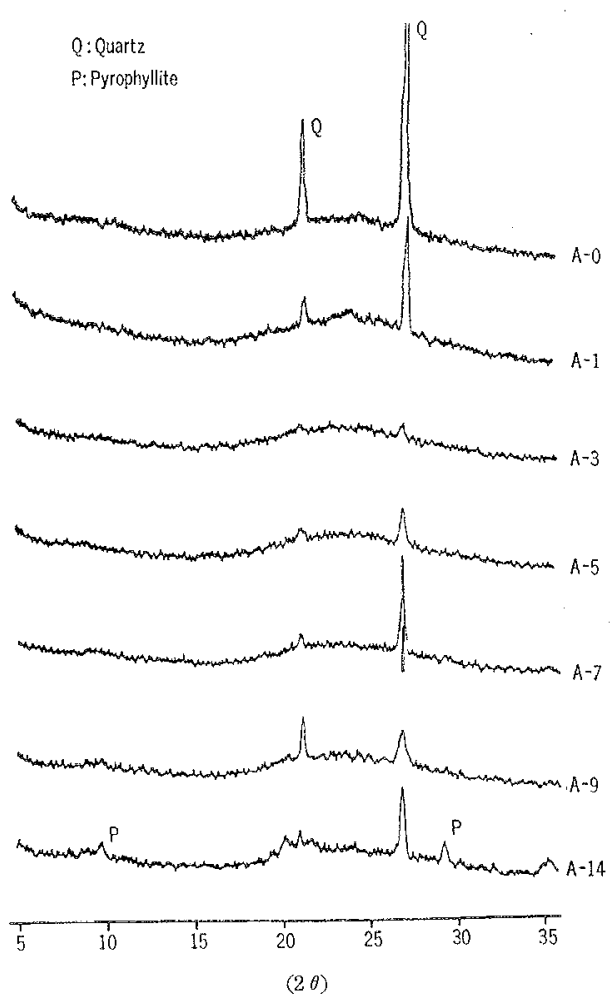

Fig. 9. X-ray diffraction patterns for the insoluble residue. at $175^{\circ} \mathrm{C} 24 \mathrm{hr}$.

この結果を図-8（8 時閪水熱処理の試料）执よび図一 9 (24 封間水熱処理を試料) に示す. これから明らかな よらに石英とパイロフィライトが不溶残分中に未反応物 質しして検出された加，これを前揭の図一1 と刘比させ れば，つぎのごとくパイロフィライトの反応性を認める ことができる。即ち罒-1 の原料混合物で峙パイロフィ ライトの強い回折がみられ, 水熱处理後で好 8 時間処理 の試料でも，その回折強度は大きく低下し，特に 24 時 
間処理ではA-14の試料の办に回折がみられたにすぎな かった.この結果忬，不溶残のX線回折でも図一8，図一 9 に示子ように全く同様な結果を示し，パイロフィライ

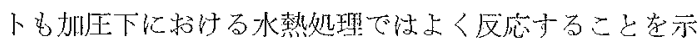
したものである。

\section{4. 総括}

1) 從来踓反忘性と考えられていたパイロフィライト が， $\mathrm{CaO}-\mathrm{Al}_{2} \mathrm{O}_{3}-\mathrm{SiO}_{2}-\mathrm{H}_{2} \mathrm{O}$ 系の水㸓反灾においてはよ く反応し，特にトベルモライトの合成では $\mathrm{Al}_{2} \mathrm{O}_{3}$ とし て 3〜5\% 程度までこれを添加することによりその結晶 生成を促谁する。

2) 結晶格子のパラメーターの増減は，トベルモライ トの結晶度で岒な，トベルモライト中の Si と Alの 置換量によって決をるむのである。

3）トベルモライト中の $\mathrm{Si} と \mathrm{Al}$ が置換する限界は, アルミナ添加量が $7 \%$ 付近にある。

4）電子顕微鏡では生成物がトベルモライトの板状結 晶を示していることを確認できるが，これが含アルミナ か，無アルミ十のトベルモライトかの区別故できない。

しかし雪子線回折を行ならことにより， $\mathrm{Al}^{3+}$ イオン の置換による構造不整が起り，k=oddレイヤ一で特徴 あるストリークを示すこと，および(300) の所でスポッ ト状の強、スリーク学示すことなどから，含アルミナ ・トベルモライトと無アルミナ・トベルモライトの区别 注可能である。ぬたこの区别はX線回折，示差熱分析結 果を併せ検討寸ればより明確となる。

5）示差熱分析ではトベルモライトの発熱ピークがア ルミナの反応量により変化子る. 即ちアルミニウム䁂換 の置が増大寸ることにより，無アルミナトベルモライト の $830^{\circ} \mathrm{C}$ 付近の発熱ピークが，含アルミナ・トベルモ ライトでは $850^{\circ} \mathrm{C}$ 付近に移り，ハイド口・ガ一ネット が生成すると $880^{\circ} \mathrm{C}$ 以上の高温域へ移行する。

6) 化学分析ではアルミナ添加量が $3 \%$ の場合， $175^{\circ} \mathrm{C}, 8$ 時閒の水熱処理で $83 \% ， 24$ 時閒の水熱処理で 估 $93 \%$ 反応し，最低でもその添加量が $14 \%$ のをに 8
時閒の水熱処理で 54\% 以上, 24 時間の水熱処理で $63 \%$ 以上反応したことが確認され，この結果とX線回折結果 を併也検討することによってより明確にパイロフィラ イトの区志性裳知ることができ，パイロフィライトも工

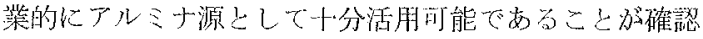
され炡。

朴研究に祭し，電子顕微鏡，電子圆析で大服工業技術試験所

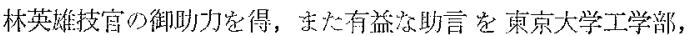

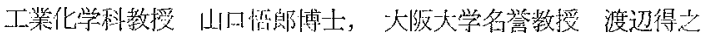
助博上より頂いた。ここに哚甚の謝意を表する。文た本研究の 発表を許可された大阪パッキング製造所社長、楠木克己氏に愿 く机礼申し上你る。

\section{文献}

1) G.L. Kalousek, J. Am. Ceram. Soc. 40, 74, (1957).

2) 真木順三, 上田 知, 小泉光惠, 久保和彦, 暂業協会 3 支部合同秋期研究発表講濱要旨; 女ラミック 2[10] 839 (1967).

3) 近藤連一, 大沢栄世, 松丸 裕, 北村 勝, 加東宮明, 女 メント技報, 2192 (1967).

4) J.N. Fuchs, Dingl. polyt. J. 49, 271 (1833).

5) H.Le. Chatelier, "Experimental researches on the constitution of Hydraulic Mortartars," translated by T. Mack, McGraw publishing Co. New York (1905).

6) E. Jordis und E.H. Kanter, Z. Anorg. Chem. 35, 82 (1903).

7) 永州彰一郎, 工化, 34, 619, 867 (1931).

8) L. Heller and H.F.W. Taylor, J. Chem. Soc. 2397 (1951), 1018 (1952), 2535 (1952).

9) H.F.W. Taylor, "Chemistry of Cements", Academic Press (1964).

10) G.L. Kalousek and A.F. Prebus, J. Am. Ceram. Soc. 41, 124 (1958).

11) S. Diamond, J.L. White and W.L. Dolch, Am. Mineral. 51, 388 (1966).

12) D.M. Roy and A.M. Johonson, Int. Sym. Autoclaved Calcium Silicste building Products," Sec. II, pap. No. 8 (1965).

13) H.D. Megaw and C.H. Kelsey, Nature, 197, 390 (1970).

14）高橋 輝, 渡辺康義, “第 14 回応用鉱物関係連合講演会” p 19-8-B, 224 (1968).

[5/21/1970 受付 $]$ 